\title{
Ne bis in idem, nulla poena sine lege and Domestic Prosecutions of International Crimes in the Aftermath of a Trial at the International Criminal Court
}

\author{
Keilin Anderson \\ LLM Candidate, International Law, Australian National University, Canberra, \\ Australia \\ keilin.anderson@uqconnect.edu.au \\ Adaena Sinclair-Blakemore \\ LLM Candidate, International Law, University of Cambridge, Cambridge, UK \\ asinclairblakemore@gmail.com
}

\begin{abstract}
The outcome of an ICC trial - be it a conviction or acquittal - receives significant attention. However, what happens to a defendant in the aftermath of the proceeding garners little discussion. This article seeks to fill this gap in the literature by analysing how the ne bis in idem and nulla poena sine lege principles, enshrined in Articles $2 \mathrm{O}(2)$ and 23 of the Rome Statute, protect defendants from subsequent prosecutions and punishments by states and regional courts following their trials at the ICC. We argue that these provisions do not provide adequate protection. Further, we argue that given the ICC's limited power to enforce compliance with these provisions as well as the primary role that states enjoy in the enforcement of international criminal law, the most appropriate way to address this issue is through the inclusion of robust protections in domestic legislation and the constituent instruments of regional courts.
\end{abstract}

\section{Keywords}

International Criminal Court (ICC) - Rome Statute - ne bis in idem - nulla poena sine lege - domestic prosecution - punishment - complementarity 
What happens to a defendant after they have been convicted or acquitted by the International Criminal Court (ICC, the Court)? The outcomes of ICC trials receive significant media and scholarly attention: convictions are lauded as positive reinforcements that the ICC is an effective institution delivering on its mandate of ending impunity, ${ }^{1}$ whereas acquittals are criticised as a 'blow for victims' and a failure of the Court to deliver justice. ${ }^{2}$ Whilst the outcome of an ICC trial is heavily scrutinised, far less attention is paid to the aftermath of the trial and, specifically, what happens to a defendant after the verdict. Where attention has been paid to post-trial issues, the focus has been on the challenges associated with, for example, defendants seeking asylum and obtaining compensation for time wrongfully spent in detention. ${ }^{3}$ Far less consideration has been given to how the Rome Statute of the International Criminal Court (Rome Statute, Statute) $)^{4}$ protects defendants from subsequent prosecutions and punishments by domestic and regional authorities.

This article aims to fill this gap in the literature by critically analysing the rights that a convicted or acquitted defendant has post-proceeding, particularly the right not to be tried or punished twice for the same crime under international criminal law. We draw on two recent examples of defendants who faced subsequent prosecutions and punishments by states following their

Acknowledgments: The views expressed in this article are our own and do not necessarily reflect those of the institutions and organisations with which we are or have been affiliated. E.g., Amnesty International, 'DRC: ICC Conviction of Ntaganda Provides Long-Awaited Justice for Victims of Grotesque Crimes', Amnesty International, 8 July 2019, www.amnesty. org/en/latest/news/2019/o7/drc-icc-conviction-of-ntaganda-provides-long-awaited-justicefor-victims-of-grotesque-crimes/. All websites were accessed on 26 April 2020, unless otherwise indicated.

E.g., Luke Moffett, 'Why Gbagbo Acquittal is a Bigger Blow for the ICC than the Bemba Decision', The Conversation, 16 January 2019, www.theconversation.com/ why-gbagbo-acquittal-is-a-bigger-blow-for-the-icc-than-the-bemba-decision-109913.

E.g., Emma Irving, 'When International Justice Concludes', 15 Journal of International Criminal Justice (2017) 115-131; Joris Van Wijk, 'When International Criminal Justice Collides with Principles of International Protection: Assessing the Consequences of ICC Witnesses Seeking Asylum, Defendants Being Acquitted, and Convicted Being Released', 26 Leiden Journal of International Law (2013) 173-191; Dersim Yabasun and Mathias Holvoet, 'Seeking Asylum before the International Criminal Court: Another Challenge for a Court in Need of Credibility', 13 International Criminal Law Review (2013) 725-745; Johan David Michels, 'Compensating Acquitted Defendants for Detention before International Criminal Courts', 8 Journal of International Criminal Justice (2010) 407-424.

4 Rome Statute of the International Criminal Court (adopted 17 July1998, entered into force 1 July 2002) 2187 UNTS $_{3}$ (Rome Statute). 
trials at the ICC to argue that the interpretation and application of the main provisions in the Rome Statute that regulate subsequent punishment or proceedings, namely the principles of ne bis in idem and nulla poena sine lege, do not adequately protect defendants from subsequent prosecution and punishment by domestic and regional authorities. We propose that whilst greater protection could be provided by broadening the scope of these principles in the Rome Statute, the difficulty of achieving consensus among state parties to amend the Rome Statute, combined with the fact that under the principle of complementarity domestic courts have the primary role in the enforcement of international criminal law, mean that the most appropriate solution to this issue lies at the domestic and regional levels. Further, we discuss how the current push towards a notion of 'positive complementarity', which encourages states to take a more active role in the domestic prosecution of international crimes, along with the proliferation of regional and hybrid courts whose jurisdictions overlap with that of the ICC, mean instances of subsequent prosecution and punishment will only become more frequent. We argue that this trend also confirms the vital, and indeed primary, role that states have in ensuring their municipal systems fill the gaps left by an inadequate level of protection in the Rome Statute.

The structure of this article is as follows. Part 2 provides an overview of the provisions of the Rome Statute and the Rules of Evidence and Procedure $(\mathrm{RPE})^{5}$ that govern the rights of convicted and acquitted defendants in the aftermath of ICC proceedings. Parts 3 and 4 analyse how the principles of $n e$ bis in idem and nulla poena sine lege, which are codified in Articles 20 and 23 of the Statute respectively, regulate the extent to which a defendant may be subject to subsequent prosecution and/or punishment following their conviction or acquittal by the Court. In particular, we consider the Court's approach to subsequent prosecution and/or punishment when it has arisen in the cases of Germain Katanga and Jean-Pierre Bemba Gombo. In Part 5 we propose that, in light of the inadequate protections provided for in the Rome Statute, international criminal law must look for solutions at the domestic and regional levels. We analyse existing domestic legislation and provide best practice recommendations for drafting protections into domestic laws and the constituent instruments of regional and hybrid courts that have jurisdiction to try international crimes. 


\subsection{Post-Conviction Processes under the Rome Statute}

The Rome Statute includes several provisions outlining the procedures to be followed after a defendant has been convicted. These include sentencing, ${ }^{6}$ the right of the defendant to appeal the conviction, ${ }^{7}$ the establishment of a trust fund and the awarding of reparations to victims, ${ }^{8}$ and the enforcement of prison sentences and fines. ${ }^{9}$

The Rome Statute and the RPE also provide a framework for the transfer of a convicted person to a state for the enforcement of the person's sentence ${ }^{10}$ and for the transfer of a person to a state upon their release after having served their sentence. ${ }^{11}$ Notably, Article 108 of the Statute provides that, without the Court's approval, a person in the custody of the state of enforcement, 'shall not be subject to prosecution or punishment or to extradition to a third State for any conduct engaged in prior to that person's delivery to the State of enforcement'. Article 108, on its face, affords a convicted person protection from simultaneous prosecution and punishment while they are serving their Rome Statute sentence. Therefore, the provision assumes great relevance to the issues considered in this article. However, recent practice reveals that the Presidency will interpret Article 108 narrowly and will be reticent to refuse authorisation of a subsequent domestic proceeding. ${ }^{12}$ The implications of this approach are discussed in further detail in Part 3 with respect to the domestic prosecution of Germain Katanga by the Democratic Republic of the Congo (DRC) following the serving of his sentence for his ICC convictions.

\subsection{Post-Acquittal Processes under the Rome Statute}

Unsurprisingly, there are far fewer provisions concerning post-acquittal processes. Following an acquittal, the Rome Statute provides that 'the accused shall be released immediately'13 and the RPE require the Registry to make

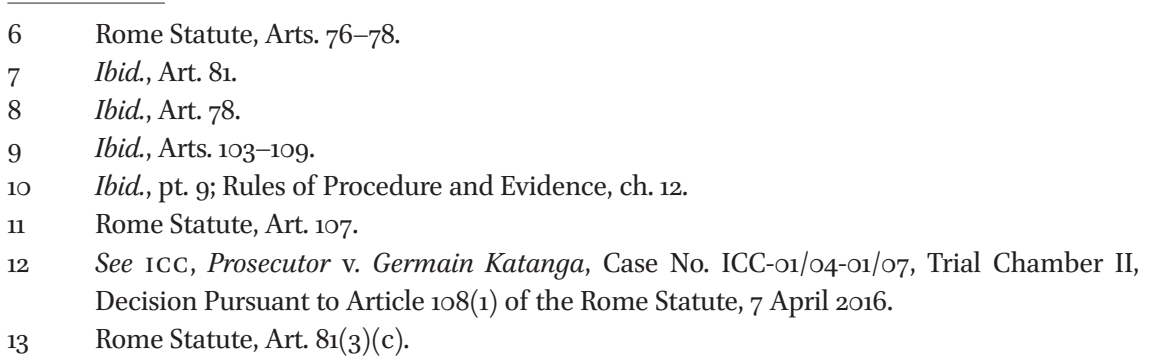


arrangements to transfer the acquitted defendant to a state that is willing to receive him or her. ${ }^{14}$ Acquitted defendants are also entitled to make a claim for compensation for time wrongfully spent in detention, which the Court has discretion to award where there has been a grave and manifest miscarriage of justice. ${ }^{15}$ Indeed, following his acquittal by the Appeals Chamber in June 2018, Jean-Pierre Bemba Gombo was unsuccessful in his attempt to claim EUR 68.8 million in compensation and damages for ten years' imprisonment and the handling of significant assets which had been frozen by the Court. ${ }^{16}$

Apart from the abovementioned provisions, the Rome Statute framework on post-conviction and post-acquittal processes is sparse. This is unsurprising given that the drafters' efforts were focused on the establishment of the Court rather than the post-proceeding issues that might arise in the longer term. ${ }^{17}$ The travaux préparatoires are notably silent on the question of why the drafters did not include great detail on the legal issues that may arise in the aftermath of an ICC trial. Various opinions have been proffered as to why this is the case, ranging from the idea that the international community was overwhelmingly focussed on drafting the Rome Statute and ensuring accountability such that the aftermath of a proceeding was an afterthought, ${ }^{18}$ to the assertion that the drafters merely did not foresee the likelihood of numerous acquittals occurring and were therefore not concerned with the legal status of acquitted individuals. ${ }^{19}$ Whatever the explanation for the lack of rules regarding post-proceeding issues, there are now numerous examples of the legal and practical issues faced by defendants who have been released following the serving of their sentence or following their acquittal that highlight the need for greater clarity on the legal status of ICC defendants in the aftermath of their trial. These include, as foreshadowed, seeking asylum and obtaining compensation for wrongful detention. However, of particular relevance to this article are the inadequate protections in the Rome Statute and the RPE regarding

14 Rules of Procedure and Evidence, r. 185.

15 Rome Statute, Art. 85(3).

16 ICC, Prosecutor v. Jean-Pierre Bemba Gombo, Case No. ICC-o1/o5-o1/o8, Pre-Trial Chamber II, Decision on Mr Bemba's Claim for Compensation and Damages, 18 May 2020.

William A. Schabas (ed.), The International Criminal Court: A Commentary on the Rome Statute (Oxford University Press, Oxford, 2016), pp. 386-387.

Benoit Henry, 'The Acquitted Accused: A Forgotten Party of the ICTR', 12 New England Journal of International and Comparative Law (2005) 81-88, 81; see also Kevin Jon Heller, 'What Happens to the Acquitted?', 21 Leiden Journal of International Law (2008) 661-68o, 663 .

Henry, supra note 18, p. 88. 
subsequent prosecution and punishment of convicted or acquitted defendants by domestic and regional courts following the completion of their ICC trials.

\section{Ne bis in idem and Protection from Subsequent Prosecution and Punishment}

Article 20 of the Rome Statute enumerates the principle of ne bis in idem, often referred to in common law jurisdictions as the prohibition against double jeopardy. Whilst international criminal law has a robust understanding of ne bis in idem in terms of when the ICC can initiate an investigation and prosecution after a state is deemed 'unwilling or unable' to prosecute, lingering questions associated with what happens if states become willing or able after an ICC proceeding represent a problematic gap in the system. In this Part, we analyse the content of Article 20 as it applies to ICC defendants after the outcome of their trial and argue that the principle offers limited protection to defendants who are facing subsequent prosecution and punishment by states or regional courts.

\subsection{Ne bis in idem in International Law and Domestic Laws}

The basic premise of ne bis in idem (literally 'not twice about the same') is that individuals must not be tried or punished twice for the same crime. The rationale behind the principle is twofold. First, it protects a defendant from the distress criminal proceedings may cause by not affording the state a second chance to make its case. Secondly, it protects the integrity and credibility of the legal process by respecting the finality of judgments. ${ }^{20}$

With a long history that can be traced back to ancient Greek and Roman laws ${ }^{21}$ the principle is today enshrined in the domestic criminal laws of almost all states, ${ }^{22}$ international and regional human rights treaties, ${ }^{23}$ bilateral and multilateral extradition treaties and the constituent instruments of

Immi Tallgren and Astrid Reisinger Coracini, 'Article 20: Ne Bis In Idem', in Otto Triffterer (ed.), Commentary on the Rome Statute of the International Criminal Court: Observers' Notes, Article by Article (Hart, London, 2008), 669-699, pp. 671-672. Nemo debet bis vexair pro una et eadam causa: no man should be proceeded against twice for the same cause.

22 E.g., German Constitution, Art. 103(3); South Africa Constitution, Art. 35(3)(m).

23 Protocol 7 to the European Convention for the Protection of Human Rights and Fundamental Freedoms (opened for signature 22 November 1984, entered into force 1 November 1988) Art. 4(1); American Convention on Human Rights (opened for signature 22 November 1969, entered into force 18 July 1978) art. 8(4). 
international criminal tribunals and the ICc. However, although the basic notion of ne bis in idem is widely accepted across national jurisdictions, in reality its exact scope and meaning varies significantly across domestic systems and international treaties which limits its protective function.

The first qualification to the principle is that despite its near-universal recognition, it applies within one jurisdictional system only. ${ }^{24}$ Therefore, the principle does not prohibit a person from being tried in a second state for the same crime for which he or she was tried in another state. ${ }^{25}$ The consequences of this have been extensively analysed. ${ }^{26}$ Numerous scholars have advocated for the recognition of a 'transnational ne bis in idem' principle, where states would observe and enforce ne bis in idem as between states, rather than only within one state. ${ }^{27}$ However, the recognition of transnational ne bis in idem by states remains limited. ${ }^{28}$

The second important qualification to the principle is that its content differs between jurisdictions. As a corollary of the fact that ne bis in idem applies within one jurisdiction only, each jurisdiction can interpret and apply the principle in accordance with its domestic laws. Significantly, there are differing interpretations of the 'idem' element, which requires consideration of what constitutes the 'same' acts or conduct. Is a subsequent prosecution prohibited only if the individual is going to be tried for the exact same crime? Or is a subsequent prosecution prohibited if an individual is to be tried for a different crime, involving the same conduct as the crime for which they were previously tried? The former would provide a weaker protection to an accused whereas

24 United Nations Human Rights Committee (UNHRC), General Comment No. 32, Article 14: Right to Equality before Courts and Tribunals and to a Fair Trial (CCPR/C/GC/32), para. 57; Linda Carter, 'The Principle of Complementarity and the International Criminal Court: The Role of Ne Bis In Idem', 8(1) Santa Clara Journal of International Law (2010) 165-198, p.171. The UNHRC has, however, encouraged states to recognise transnational ne bis in idem through bilateral or multilateral agreements: UNHRC, supra note 24, para. 57. Christoph Grabenwarter, European Convention on Human Rights: Commentary (C.H. Beck /Hart, Munich/Oxford, 2014), p. 437; Juliette Lelieur, “Transnationalising” Ne Bis In Idem: How the Rule of Ne Bis In Idem Reveals the Principle of Personal Legal Certainty', 9 Utrecht Law Review (2013) 198-210, p. 198.

27 E.g., André Klip, 'Jurisdiction and Transnational Ne Bis In Idem in Prosecution of Transnational Crimes', in Darryl K. Brown et al., (eds.), The Oxford Handbook of Criminal Process (Oxford University Press, Oxford, 2019), 477-499. the principle among EU member states: see $\mathrm{ECJ}$, Joined Cases of Gözütok and Brügge, nos. C-187/o1 and C-385/o1, Judgment, 11 February 2003. 
the latter provides a stronger protection. ${ }^{29}$ In international human rights law, Article 14(7) of the International Covenant on Civil and Political Rights (ICCPR) and Article 4(1) of Protocol 7 to the European Convention for the Protection of Human Rights and Fundamental Freedoms both prohibit subsequent prosecutions for the same 'offence'. However, while the ICCPR provision has been construed narrowly such that a subsequent prosecution is only barred if the legal characterisation of the charges is the same as in the first proceeding, ${ }^{30}$ the European Court of Human Rights has rejected a narrow interpretation of Article 4(1) and has adopted an interpretation based on 'identical facts or facts which are substantially the same.'31

\subsection{Ne bis in idem in the Rome Statute}

When considering how the principle of ne bis in idem applies in the context of the ICC, it is not so simple to say that it applies within one jurisdictional regime only. This is because the ICC's jurisdiction complements, but does not supplement, a state's jurisdiction to prosecute. Unlike in domestic legal systems, which operate concurrently, the ne bis in idem principle in the Rome Statute applies between a supranational jurisdiction (the ICC) and a domestic jurisdiction (the state). Accordingly, the ne bis in idem principle in the Rome Statute must be considered in a sui generis context because it applies across jurisdictions, as opposed to only within one jurisdiction. ${ }^{32}$

The principle of ne bis in idem is expressed in Article 20 of the Rome Statute, which is contained in Part 2 of the Statute: 'Jurisdiction, Admissibility and Applicable Law'. The significance of this is that the principle is not only a fair trial right but is also a limit on the ICC's jurisdiction to prosecute..$^{33}$

Whilst Article 20(2) of the Rome Statute is the most relevant to this article as it regulates the 'downward' relationship between the ICC and a domestic court seized second in time, it is helpful to consider the provision as a whole.

Article $20(2)$ provides that:

1. Except as provided in this Statute, no person shall be tried before the Court with respect to conduct which formed the basis of crimes for which the person has been convicted or acquitted by the Court.

\footnotetext{
29 Carter, supra note 24, pp. 170-171, 189.

$30 \quad$ UNHRC, supra note 24 , para. 54 .

31 European Court of Human Rights, Zolotukhin v. Russia, Case No. 14939/o3, Judgment, 7 June 2007, paras. 81-82.

32 Tallgren and Coracini, supra note 20, pp. 686-687.

33 Carter, supra note 24, p. 176.
} 
2. No person shall be tried by another court for a crime referred to in Article 5 for which that person has already been convicted or acquitted by the Court.

3. No person who has been tried by another court for conduct also proscribed under Article 6, 7, or 8 shall be tried by the Court with respect to the same conduct unless the proceedings in the other court:

(a) Were for the purpose of shielding the person concerned from criminal responsibility for crimes within the jurisdiction of the Court; or

(b) Otherwise were not conducted independently or impartially in accordance with the norms of due process recognized by international law and were conducted in a manner which, in the circumstances, was inconsistent with an intent to bring the person concerned to justice.

Article 20 includes both 'horizontal' ne bis in idem and 'vertical' ne bis in idem.

\subsection{1}

Horizontal ne bis in idem

The first subsection (Article 2o(1)) deals with ne bis in idem as it applies to the ICC's own decisions. This is the simplest form of ne bis in idem enshrined in the Rome Statute, dealing only with one Court and one 'level' of legal system. Article 20(1) protects a person who has previously been convicted or acquitted by the ICC. This 'horizontal' ${ }^{34}$ protection is comprehensive due to the reference to 'conduct which formed the basis of crimes'. Therefore, irrespective of complex questions about the characterisation of the 'idem' element, Article $20(1)$ protects individuals from two ICC trials on the same facts. For example, if an individual is convicted or acquitted of the crime against humanity of torture by the ICC, Article 2o(1) prevents them being subsequently tried for, by way of example, rape - so long as the conduct underlying the rape and torture charges is the same. $^{35}$

\subsubsection{Vertical $n$ ne bis in idem}

The second and third subsections (Articles $20(2)$ and (3)) deal with the effects of decisions of other courts, or a 'vertical' application ne bis in idem. Article

$34 \quad$ See especially Carter, supra note 24, p. 172.

35 Interestingly, whilst Art. 2o(1) restricts a subsequent proceeding for the same conduct, the ICC's current approach to cumulative charging and convictions would allow an individual (once before the ICC) to be charged and ultimately convicted of both murder and genocide for the same underlying conduct on the basis of the prevailing test from: ICC, Prosecutor v. Bosco Ntaganda, Case No. ICC-o1/o4-02/06, Trial Chamber vI, Judgment, 8 July 2019, para. 1202. 
20 (3) addresses the effect of a national decision on the jurisdiction of the Court - or, 'upward' ne bis in idem. This is where the intimate link between ne bis in idem and complementarity becomes patent. As described in commentaries to the Statute, Article 2O(3) represents 'the last safeguard in allocating the tasks of national and international criminal justice according to the notion of complementarity'. ${ }^{\prime 6}$ There is a clear link between Article 20(3) and Article 17 which limits the ICC's jurisdiction to cases where a state is 'unwilling or unable' to investigate or prosecute. Article $17(1)$ (c) expressly reinforces that a case is inadmissible before the Court where the person 'has already been tried for conduct which is the subject of the complaint'. The majority of literature on Article 20 therefore focuses on subsection (3) and the complex questions it raises about exactly what 'conduct' in this context means. ${ }^{37}$

However, as foreshadowed, it is Article 20(2) that is of most relevance to the questions at the heart of this article. Article 20(2) regulates 'downward' ne bis in idem, or the impact an ICC decision has on the ability of another court to subsequently try an individual. Notably, the subsection provides a considerably more diluted protection for individuals than subsections (1) and (3). Instead of referring to 'conduct', the subsection refers, specifically, to 'a crime referred to in article 5'. Therefore, with respect to other courts, individuals are only protected where another court seeks to try the individual for the specific crimes enumerated in Article 5: genocide, war crimes, crimes against humanity and the crime of aggression. ${ }^{38}$ Consequently, an accused who is acquitted by the ICC of genocide could subsequently be tried by a domestic or regional court for a crime such as murder, or potentially for another Article 5 crime such as the crime against humanity of persecution. Therefore, whilst on its face Article $2 \mathrm{O}(2)$ seems to protect an individual from facing subsequent prosecution, the inclusion of 'for a crime referred to in Article 5' rather than 'conduct' (as in Articles $2 \mathrm{O}(1)$ and $2 \mathrm{O}(3)$ ) considerably narrows the protection afforded to individuals tried first by the ICC.

Of course, many would agree that if, for example, the ICC were to acquit an accused of rape as a crime against humanity, a domestic court should, as a matter of both law and policy, be able to pursue a prosecution for rape as an 'ordinary' crime. ${ }^{39}$ We do not seek to propose that subsequent prosecution after an ICC proceeding is, prima facie, problematic. There may be compelling

$36 \quad$ Tallgren and Coracini, supra note 20, p. 672.

$37 \quad$ Schabas, supra note 17, p. 509.

38 Ibid., p. 5 o8.

39 André Klip and Harmen Van Der Wilt, 'The Netherlands Non Bis In Idem', 73 Revue Internationale de Droit Pénal, (2002) 1091-1137. 
legal and policy reasons for and against the subsequent domestic prosecution of an accused for the same, or similar, crimes. However, what is concerning is the rigid requirement that a domestic proceeding must be 'for a crime referred to in Article 5' because this reduces considerations of ne bis in idem, which are necessarily nuanced, to a matter of form over substance. ${ }^{40}$ The drafting of Article 2O(2) leaves no room for considerations of the particular facts or underlying conduct of the criminal charges. This restriction is compounded by the fact that ICC charges are multi-layered and 'composite'. Therefore, it will be rare that they mirror domestic criminal charges making it unlikely for Article $20(2)$ to operate as a bar to subsequent domestic proceedings. ${ }^{41}$ While it is true that numerous state parties to the Rome Statute have implemented the Statute's Article 5 crimes into their domestic criminal legislation, many have nonetheless continued to charge individuals with ordinary crimes under domestic law rather than with international crimes under their domestic laws that implement the Rome Statute. ${ }^{42}$ For example, although legislation exists in Australia to charge individuals with Rome Statute Article 5 crimes, Australia has resisted the opportunity to do so and has instead charged individuals with ordinary crimes..$^{43}$ This practice of charging an individual with ordinary crimes does not result in a state infringing the strict letter of Article 20(2) because the domestic charges for ordinary crimes do not exactly mirror the international charges and, therefore, the defendant will not be protected from a subsequent proceeding. Indeed, the fact that the ICC is not a court of general jurisdiction but is rather concerned only with the most serious of crimes, means 'it may well be the rule rather than the exception' that individuals are subject to multiple prosecutions for a number of related crimes. ${ }^{44}$

Schabas, supra note 17, p. 508; Carter, supra note 24, p. 193.

41 Patryk Labuda, 'Complementarity Compromised? The ICC Gives Congo the Green Light to Re-Try Katanga', Opinio Juris, 11 April 2016, www.opiniojuris.org/2016/04/11/ complementarity-compromised-the-icc-gives-congo-the-green-light-to-re-try-katanga/. See Philip Kastner, 'Domestic War Crimes Trials: Only for Others - Bridging National and International Criminal Law', 39 University of Western Australia Law Review (2015) 29-50, p. 35; see also Ward N. Ferdinandusse, Direct Application of International Criminal Law in National Courts (TMC Asser Press, The Hague, 2006), pp. 89-127.

See Re Civilian Casualty Court Martial (2011) 259 FLR 208; Joshua Kelly, 'Re Civilian Casualty Court Martial: Prosecuting Breaches of International Humanitarian Law Using the Australian Military Justice System', 37 Melbourne University Law Review (2013) 342-371. the International Criminal Court: Observers' Notes, Article by Article (Hart, London, 2008), 1671-1676, p. 1675 . 
Recourse to the travaux préparatoires confirms that this dilution of ne bis in idem was a deliberate choice to preserve states' rights to charge individuals for 'ordinary' crimes under domestic law. ${ }^{45}$ Until the last session of the Preparatory Committee at the Rome Conference, draft Article 20(2) contained the wording 'for conduct constituting an Article 5 crime' rather than the narrower 'for a crime referred to in Article 5. While some delegations recognised this narrower drafting may 'undermine the protection of ne bis in idem completely' because it would afford states a broad power to initiate a subsequent prosecution for the same conduct which formed the basis of the accused's charges before the ICC, other delegations fiercely opposed restricting the scope of Article 2O(2) as it could create 'loopholes' through which an accused could escape prosecution and punishment and would therefore run counter to the ICC's goal of ending impunity. ${ }^{46}$ Following protracted debate on the issue, the narrow text that we have today was agreed upon. ${ }^{47}$ The decision to adopt the narrower wording was justified on the basis that a broader provision would infringe upon states' powers and undermine the principle of complementarity. ${ }^{48}$ Consequently, Article $20(2)$ grants states wide leeway to prosecute an individual following their conviction or acquittal by the ICC.

In addition to the narrow protection which results from the drafting of Article $20(2)$, an unfortunate enforceability gap also exists. The Court is without any power to enforce Article $20(2)$ which is instead directed at a national court seized of a subsequent proceeding. It is for this reason that state parties, who must comply with Article 2o(2), should consider implementing legislation that mitigates against a breach of Article $2 \mathrm{O}(2)$, a solution we consider in detail in Part $5{ }^{49}$

Article $20(2)$ is also narrower than its counterpart provisions in the statutes of the ad hoc tribunals, which prohibit subsequent domestic prosecutions for 'acts' for which that person has already been tried by the tribunals. ${ }^{50}$ Of course, the ad hoc tribunals were established to have primary jurisdiction to decide whether the accused would be tried under domestic criminal laws or at the ad hoc tribunals. In contrast, the ICC was established on the principle of complementarity which affords states the power to decide whether an individual

\footnotetext{
45 Tallgren and Coracini, supra note 20, p. 696.

$46 \quad$ Ibid., pp. 67o, 686.

47 Ibid.

48 Schabas, supra note 17, p. 508.

49 Ibid.

50 Statute of the International Tribunal for Rwanda (adopted 8 November 1994) S/RES/955, Art. 9(1); Statute of the International Criminal Tribunal for the Former Yugoslavia (adopted 25 May 1993) S/RES/827, Art. 10(1).
} 
should be tried under domestic laws or whether it would be best for an ICC prosecution. ${ }^{51}$

Arguably, the nature of the ICC's complementary jurisdiction makes subsequent domestic proceedings relatively unlikely. A case only will have only reached the Court where the Article 17 and Article 20(3) safeguards have been met. However, we argue that it is increasingly possible to conjure hypothetical examples. For example, by the time an ICC proceeding has run its course (whatever the outcome may be), considerable time will have passed. Picking up where the ICC left off could be a strategic move for new governments that may suddenly become 'willing and able' within the meaning of Article 17. This is particularly so where, as outlined in Part 5 , we see a more 'positive' notion of complementarity and an increased appetite for domestic and regional justice. Moreover, as the ICC moves into its third decade of operation, we will begin to see convicted defendants released following the completion of their sentences. For example, the first defendant convicted by the ICC - Thomas Lubanga Dyilo - was released in March 2020 from prison in the DRC where he was serving the remainder of his ICC sentence and it remains to be seen whether he will be charged in the DRC with domestic war crimes charges as was Katanga. ${ }^{2}$

\subsection{Article 2o(2) in Prosecutor $v$. Germain Katanga}

The limited protection afforded to ICC defendants by Article 2O(2) is exemplified by the domestic proceedings against Katanga. In the course of considering Article 108 of the Statute, the Court confirmed its interpretation of Article $20(2)$ as affording only a very narrow degree of protection from subsequent domestic proceedings. Katanga was convicted by the ICC of war crimes and crimes against humanity in relation to a 2003 attack committed by the Résistance Patriotique d'Ituri on a village in Bogoro, DRC, ${ }^{53}$ and sentenced to twelve years' imprisonment, part of which he served in a prison in the DRC. After his sentence had been served, the DRC authorities charged him with war crimes under domestic law, therefore enlivening Article 20(2). Pursuant to Article 108(1) of the Rome Statute, which allows domestic prosecutions of ICC defendants currently serving ICC sentences with the permission of the

$51 \quad$ Carter, supra note 24, p. 189.

$5^{2} \quad$ Wairagala Wakabi, 'Lubanga, ICC Convict No.1 and Longest-Serving Detainee, Completes His Sentence Next Week', International Justice Monitor, 11 March 2020, www.ijmonitor. org/2020/o3/lubanga-icc-convict-no-1-and-longest-serving-detainee-completes-hissentence-next-week/. ICC, Prosecutorv. Germain Katanga, Case No. ICC-o1/o4-01/o7, Trial Chamber II, Judgment pursuant to Article 74 of the Statute, 7 March 2014. 
Court, the Presidency allowed the domestic prosecution to proceed. Notably, this decision was made on the basis that a domestic prosecution for crimes not tried by the ICC does not offend the principle of ne bis in idem in Article $2 \mathrm{O}(2)$ of the Statute..$^{54}$ It is vital to emphasise here that while Article 108 protects (at least, in theory) a convicted defendant such as Katanga from a ne bis in idem situation, there is no analogous protection for an acquitted defendant. However, as the decision in Katanga highlighted, even where Article 108 does apply, its effect is significantly diluted by the narrow operation of Article 20(2).

In considering whether to authorise the DRC prosecution, the Presidency noted that Article 108 provides no criteria to guide its decision. However, it held that Article 108 should be interpreted in light of the principle of complementarity and that the Presidency's approval of the domestic prosecution should only be denied where it would 'undermine certain fundamental principles or procedures of the Rome Statute' or 'otherwise affect the integrity of the Court'.55 Katanga's Defence argued that one of these fundamental principles is ne bis in idem. The Defence submitted that a domestic prosecution should only be approved where the charged offences do not fall within the temporal and geographical ambit of the ICC investigation, ${ }^{56}$ noting that not only did the DRC charges against Katanga concern events in Ituri in 2002 and 2003, but the DRC authorities had officially requested the OTP's assistance in investigating and prosecuting these domestic charges. ${ }^{57}$

The Presidency accepted that ne bis in idem would fall within the list of 'certain fundamental principles'. Indeed, it was highlighted that the requirement in rule 214(1) of the RPE that a state seeking approval for a prosecution under Article 108(1) must provide documents detailing the intended prosecution, including a statement of the facts of the case and their legal characterisation, confirmed that the Court 'should consider the application of the principle of ne bis in idem in assessing any requests for approval. ${ }^{58}$ However, the Presidency rejected the Defence's particular interpretation of ne bis in idem, finding that the scope of protection afforded by Article 20(2) 'does not prohibit trials for pursuant to Article 108(1) of the Rome Statute, 7 April 2016, para. 23. Katanga, Article 108(1) Decision, para. 20. Observations by the Defence concerning the Continued and Unlawful Detention of Mr Germain Katanga by the Democratic Republic of Congo', 22 January 2016, para. 31. Ibid., paras. $33-45$.

$5^{8} \quad$ Katanga, Article 108(1) Decision, para. 22.
} 
conduct within the ambit of the ICC's investigations'. ${ }^{59}$ To hold otherwise would undermine the principle of complementarity. ${ }^{60}$

On a purely procedural understanding of ne bis in idem, the subsequent prosecution of Katanga may not violate the strict letter of Article 2O(2) if the DRC charges do not mirror exactly the ICC charges. However, the Presidency's interpretation of Articles $20(2)$ and 108 is concerning because it confirms the very narrow protection afforded to those who have been convicted or acquitted by the Court and are facing subsequent prosecution by domestic authorities. Notably, the Presidency reasoned that, in applying Article 108 in conjunction with Article 20(2), they could not 'widen the scope of the latter which only prohibits trial for a crime referred to in Article 5 for which that person has already been convicted or acquitted by the Court. ${ }^{61}$ Thus, the narrow protection afforded under Article $20(2)$ to which we have drawn attention clearly impacts the leaps and bounds of the Article 108 protection.

Presumably, had the Presidency been facing an interpretation of Article 108 where the domestic charges were 'for a crime referred to in article 5', Article $2 \mathrm{O}(2)$ would have afforded Katanga protection. However, this would have depended upon the precise characterisation of the domestic charges and whether they mirrored the ICC charges. In Katanga's case, ascertaining the precise characterisation of the domestic charges would have been a challenge in and of itself because the detail of the domestic charges against him was sparse. ${ }^{62}$ Considering the difficulties associated with comparing the characterisation of international crimes across domestic and international systems, it is no easy feat for the ICC, the parties, or even domestic authorities to understand whether Article 2O(2) is enlivened and it remains to be seen how the ICC may interpret and apply Article $20(2)$ in such a case.

This issue also raises the broader question as to whether the ICC is responsible for ensuring that domestic prosecutions safeguard the accused's fair trial rights. Katanga's Defence argued that the DRC authorities have shown a 'blatant disregard' for his fair trial rights. ${ }^{63}$ However, in its judgment, the Presidency recalled the findings of the Appeals Chamber in Prosecutor v. Saif

$59 \quad$ Ibid., para. 23.

6o Ibid.; see also ICC, Prosecutor v. Germain Katanga, Case No. ICC-o1/o4-o1/o7, Trial Chamber II, Decision on Defence Application for Reconsideration of the Presidency "Decision pursuant to Article 108(1) of the Rome Statute", 26 June 2019, para. 16.

$61 \quad$ Katanga, Article 108(1) Decision, para. 23.

62 ICC, Prosecutor v. Germain Katanga, Case No. ICC-o1/o4-o1/o7, Trial Chamber II, Defence Application for Reconsideration of the Presidency 'Decision pursuant to Article 108(1) of the Rome Statute' 20 January 2019, paras. 39-49.

$63 \quad$ Katanga, Article 108(1) Decision, para. 46. 
Al-Islam Gaddafi and Abdullah Al-Senussi that 'the Court was not established to be an international court of human rights, sitting in judgment over domestic legal systems to ensure that they are compliant with international standards of human rights.' ${ }^{6}$ Indeed, as we outline in Part 4 in respect of Prosecutor v. Bemba et al., the Court is, unsurprisingly, reticent to interfere in the domestic matters of the state. In circumstances where Article $20(2)$ is ultimately directed at a national court seized of a subsequent proceeding, the Court is left with few options beyond highlighting a state party's human rights obligations as it did in respect of the DRC and Katanga. ${ }^{65}$

The subsequent prosecution of Katanga reveals that the Court appears to interpret Article 20(2) narrowly. However, it also cements the important point that, in any event, the Court has few tools in its arsenal in circumstances where Article 2o(2) is offended, short of reminding states of their human rights obligations.

\subsection{Overcoming the Shortcomings of Article 2o(2)}

Many of the shortcomings of Article 2o(2) which we have outlined thus far could have been mitigated (or even averted) if the provision referred to 'conduct' rather than 'for a crime referred to in Article 5'. Such drafting would have ensured a more robust protection against subsequent prosecution and punishment because it would require a domestic court to consider the accused's underlying actions, rather than the mere characterisation or labelling of the international charge. However, the difficulties associated with amending the Rome Statute are patent: a majority vote of two thirds of the state parties is required and it is unlikely that there would be much appetite from state parties in support of an amendment which encroaches on their sovereignty over domestic criminal justice.

Ultimately, as the travaux préparatoires reveal, that Article $20(2)$ includes a narrower protection is a recognition of the principle of complementarity. ${ }^{66}$ Downward ne bis in idem is essentially a matter of domestic law and the domaine réservé of a state, which means that it may not be appropriate for

64 Katanga, Article 108(1) Decision, para. 31 citing ICc, Prosecutor v. Saif Al-Islam Gaddafi and Abdullah Al-Senussi, Case No ICC-o1/11-o1/11, Appeals Chamber, Judgment on the Appeal of Mr Abdullah Al-Senussi against the Decision of Pre-Trial Chamber I of 11 October 2013 entitled 'Decision on the Admissibility of the Case against Abdullah Al-Senussi', 24 July 2014, para. 219.

65 African Charter on Human and Peoples' Rights (opened for signature 28 June 1981, entered into force 21 October 1986).

66 Schabas, supra note 17, p. 508. 
these issues to be addressed via amendments to the Rome Statute. ${ }^{67}$ To that end, as discussed in Part 5 , it is vital that states consider the issues around $n e$ bis in idem when drafting and adopting their implementing legislation and ensure that their domestic laws provide adequate safeguards to persons who are being tried or punished again following their trial at the ICC.

Nulla poena sine lege and Protection from Subsequent Prosecution and Punishment

A fulsome consideration of the issues associated with the legality of subsequent prosecution and punishment of ICC defendants requires analysis not only of the principle of ne bis in idem, but also the principle of nulla poena sine lege. This principle is a fundamental tenet of domestic criminal law and is embodied in Article 23 of the Rome Statute, which provides that '[a] person convicted by the Court may be punished only in accordance with this Statute'.

Historically, Article 23 has been considered relevant only as a general principle of criminal law which guides the Court's discretion in sentencing. However, the Appeals Chamber in Prosecutor v. Bemba et al., recently considered novel arguments over the scope of Article 23, particularly, whether it prevents states from imposing additional punishments upon defendants who have been convicted by the Court. Accordingly, there now exists an unresolved question in international criminal law over the scope of Article 23 and the way in which it may serve a protective function in safeguarding defendants from the imposition of subsequent punishments by states following the conclusion of their trial at the ICc. In this Part, we focus specifically on this question and the extent to which Article 23 may serve as a limit on states' powers to punish ICC defendants following their convictions by the Court.

\subsection{Nulla poena sine lege in International Law and Domestic Laws}

Nulla poena sine lege is a component of the principle of legality, which is recognised in almost all legal systems ${ }^{68}$ and as a rule of customary international

67 Tallgren and Coracini, supra note 20, p. 687.

68 Universal Declaration of Human Rights (adopted and opened for signature, ratification and accession by General Assembly resolution 217 A(III) of 10 December 1948) art. 11(2); International Covenant on Civil and Political Rights (opened for signature 16 December 1966, entered into force 23 March 1976) 999 UNTS 171, Art. 15(1). 
law. ${ }^{69}$ The basic premise of the principle is that an individual convicted of a crime may only be punished in accordance with the penalties expressly applicable to that crime at the time the offence was committed. Along with the principle of nullum crimen sine lege, it prohibits the retroactive application of criminal laws and therefore underlies two important aspects of the rule of law: certainty and transparency. ${ }^{70}$

In domestic systems, the principle of legality typically requires that the penalties for each crime are clearly expressed. In international criminal law, nulla poena sine lege was not included as a standalone provision in the constituent instruments of the ICTY, ICTR, STL and SCSL. It was not until the drafting of the Rome Statute that nulla poena sine lege was included as a distinct provision. Consequently, the doctrinal maturity of the nulla poena sine lege principle in international criminal law remains limited.

\subsection{Nulla poena sine lege in the Rome Statute}

\subsubsection{Article 23 as a General Principle of Criminal Law}

Article 23 is contained in Part 3 of the Statute: 'General Principles of Criminal Law'. It is closely linked to the penalties and sentencing regime in that it limits the types of penalties that the ICC may impose to those laid down in Article $77,{ }^{71}$ for example, a maximum prison sentence of 30 years. ${ }^{72}$ The inclusion of the nulla poena sine lege principle in Article 23 of the Statute means that the penalties enumerated in Article 77 are 'exhaustive. ${ }^{73}$

Although the drafting history of Article 23 reveals that its adoption was uncontroversial and was designed to complement Article 22, ${ }^{74}$ the precise

$69 \quad$ Susan Lamb, 'Nullum Crimen, Nulla Poena Sine Lege in International Criminal Law', in Antonio Cassese, Paolo Gaeta and John R.W.D. Jones (eds.), The Rome Statute of the International Criminal Court (Oxford University Press, Oxford, 20o9), 733-766, pp. 734-735. See generally Franz Von Liszt, 'The Rationale for the Nullum Crimen Principle', 5 Journal of International Criminal Justice (2007) 1009-1013.

71 Gerhard Werle, 'Part A: Major Problems of International Criminal Justice, II Fundamentals of International Criminal Law, General Principles of International Criminal Law', in Antonio Cassese (ed.), The Oxford Companion to International Criminal Justice (Oxford University Press, Oxford, 2009), 54-62, p. 55.

72 Rome Statute, Art. 77.

73 Young Sok Kim, The International Criminal Court: A Commentary on the Rome Statute (Wisdom House, Leeds, 2003), p. 440; ICC, Prosecutor v. Bemba et al., Case No. o1/05-01/13, Appeals Chamber, Judgment on the Appeals of the Prosecutor, Mr Jean-Pierre Bemba Gombo, Mr Fidèle Babala Wandu and Mr Narcisse Arido against the Decision of Trial Chamber vi I entitled 'Decision on Sentence pursuant to Article 76 of the Statute', 8 March 2018, para. 77 . 
content and scope of the principle in the Rome Statute remain unclear. ${ }^{75}$ The inclusion of the nullum crimen sine lege and nulla poena sine lege principles in the Rome Statute was recognised as essential, but they were of secondary concern to other provisions, such as those defining the Article 5 crimes and outlining the Court's jurisdiction. ${ }^{76}$ Adding to the uncertainty over the application of Article 23 is the fact that it has received only 'perfunctory references' in ICC case law. ${ }^{77}$ In the few sentencing judgments delivered by the ICC so far, the respective Trial Chambers have noted the applicability of Article 23 in determining the appropriate penalty but have not elaborated on the content of the principle. ${ }^{78}$

4.2 .2

Article 23 as a Limitation on a State's Power to Impose Additional Punishments

While Article 23 has been cited and applied in a straightforward and non-controversial manner in the ICC sentencing judgments delivered to date, Prosecutor v. Bemba et al., raised a novel question about the scope of the provision: does Article 23, which confines the types of punishments that may be imposed upon persons convicted by the Court to those enumerated in Article 77 , limit the ability of states to impose additional punishments under domestic law?

This precise question arose during the re-sentencing phase of the proceedings in Prosecutor v. Bemba et al., Bemba was acquitted of all charges of war

75 Kai Ambos, 'Nulla Poena Sine Lege as a Fundamental But Imprecise Principle in International Law', in Roleof Haveman and Olaoluwa Olaoluwa (eds.), Sentencing and Sanctioning in Supranational Criminal Law (Intersentia, Atwerp, 2006), 23-27, p. 23.

$76 \quad$ Werle, supra note 71, p. 54.

77 Schabas, supra note 17 , p. 553.

78 William A. Schabas and Kai Ambos, 'Article 23: Nulla Poena Sine Lege', in Otto Triffterer and Kai Ambos (eds.), Rome Statute of the International Criminal Court: A Commentary (Oxford University Press, Oxford, 2016), 967-971, p. 968; ICC, Prosecutor v. Lubanga, Case No. 01/04-01/o6, Trial Chamber I, Decision on Sentence pursuant to Article 76 of the Statute, 10 July 2012, paras. 17-18; ICC, Prosecutor v. Katanga, Case No o1/04-01/o7, Trial Chamber II, Decision on Sentence pursuant to Article 76 of the Statute, 23 May 2014, para. 39; ICC, Prosecutor v. Katanga and Ngudjolo, Case No. o1/O4-01/o7, Appeals Chambers, Appeal against the Decision on Joinder rendered on 10 March 2008 by the Pre-Trial Chamber in the Germain Katanga and Mathieu Ngudjolo Cases, 21 April 2008, para. 18; ICC, Prosecutor v. Jean-Pierre Bemba Gombo, Case No. o1/05-01/o8, Trial Chamber III, Decision on Sentence pursuant to Article 76 of the Statute, 21 June 2016, para. 8; ICC, Prosecutor v. Ahmad Al Faqi Al Mahdi, Case No. o1/12-01/15, Trial Chamber viII, Judgment and Sentence, 27 September 2016, para. 65; ICC, Prosecutor v. Bemba et al., Case No. o1/05-o1/13, Trial Chamber viI, Decision on Sentence pursuant to Article 76 of the Statute, 22 March 2017, para. 18. 
crimes and crimes against humanity in June 2018 by the Appeals Chamber. ${ }^{79}$ However, in the parallel Prosecutor v. Bemba et al., proceedings, he, along with members of his legal team, was convicted of offences against the administration of justice pursuant to Article 70 of the Rome Statute. ${ }^{80}$ Bemba was sentenced to one additional year of imprisonment to be served consecutively to the then existing sentence pronounced against him in the main case and a fine of EUR 300,000. ${ }^{81}$ The Appeals Chamber overruled this sentencing decision and remitted it back to Trial Chamber viI for re-sentencing. ${ }^{82}$

Shortly prior to Trial Chamber viI's re-sentencing decision in September 2018, Bemba filed an Urgent Request for declaratory relief, requesting the Chamber to 'take steps to protect the right of Bemba not to be pursued and punished twice for the same conduct in different jurisdictions'. ${ }^{83}$ The Urgent Request related to a decision by the DRC Constitutional Court, which held that Bemba was ineligible to hold public office in the DRC because his conduct underlying his conviction at the Court for Article 70 offences equated to the crime of corruption under DRC law. The Defence for Bemba argued that the DRC Constitutional Court's decision: 'constitutes a severe sanction, which falls outside the legal frameworks of the Statute, and the law in force at the time of the conduct. The Decision to impose sanctions independently of the ICC therefore violates Article 23 of the Statute (nulla poena sine lege). ${ }^{84}$

The Defence's framing of this issue as a violation of Article 23 was novel. The ne bis in idem protection in Article 2o(2) does not apply to offences against the administration of justice pursuant to Article 70 of the Statute, ${ }^{85}$ which means that there is no prohibition on another court from subsequently prosecuting an individual who has been convicted or acquitted by the ICC for offences

79 ICC, Prosecutor v. Jean-Pierre Bemba Gombo, Case No. o1/o5-01/o8, Appeals Chamber, Judgment on the Appeal of Mr Jean-Pierre Bemba Gombo against Trial Chamber III's 'Judgment pursuant to Article 74 of the Statute', 8 June 2018.

See ICC, Prosecutor v. Bemba et al., Case No. o1/05-01/13, Trial Chamber viI, Public Redacted Version of Judgment pursuant to Article 74 of the Statute, 19 October 2016.

81 ICC, Prosecutor v. Bemba et al., Case No. 01/05-01/13, Trial Chamber viI, Decision on Sentence pursuant to Article 76 of the Statute, 22 March 2017, para. 273.

82 ICC, Prosecutor v. Bemba et al., Case No. o1/05-01/13, Appeals Chamber, Judgment on the Appeals of the Prosecutor, Mr Jean-Pierre Bemba Gombo, Mr Fidèle Babala Wandu and Mr Narcisse Arido against the Decision of Trial Chamber viI entitled "Decision on Sentence pursuant to Article 76 of the Statute", 8 March 2018, para. 362.

83 ICC, Prosecutor v. Bemba et al., Case No. o1/05-01/13, Trial Chamber viI, Urgent Request, 10 September 2018, para. 1 .

$84 \quad$ Ibid., para. 2.

85 Rules of Procedure and Evidence, r. 163 and r. 168. 
pursuant to Article $70 .{ }^{86}$ The principle of ne bis in idem in the Rome Statute therefore offered Bemba no recourse. Consequently, the Defence turned to Article 23 as a basis to argue against the imposition of additional punishments by a state. The Defence argued that Article 23 represents a bar to the imposition of any sanctions upon persons convicted by the court unless those sanctions are prescribed in Article 77. The Defence relied, in part, on the views of Schabas who has favoured the position that Article 23 prevents states from imposing penalties in addition to those imposed by the Court:

Article 23 serves as a limit on the discretionary powers of the Court ... It also prevents States Parties from imposing additional punishment upon those who have already been convicted by the Court. The ramifications of this remain to be determined, but offenders may argue that civil sanctions such as deprivation of the right to vote, or prohibition of holding office, constitute additional punishment and are therefore prohibited by Article $23 .{ }^{87}$

According to the Defence, the inclusion of Article 23 in the Rome Statute is 'meaningless' unless the Court is willing to prevent states from imposing additional punishments upon defendants. ${ }^{88}$ However, Trial Chamber viI rejected the Urgent Request, finding that Article 23 'is principally concerned with punishments that this Court imposes on a convicted person. A loss of the right to seek office by a domestic court is beyond its ambit' 89

On appeal, the Defence sought to relitigate its Article 23 line of argument, submitting that Trial Chamber vir had erred by refusing to apply Article 23 and safeguard Bemba from the sanctions imposed upon him in the DRC. ${ }^{90}$ The Defence argued that as Article 23 appears in Part 3 of the Statute it 'should be interpreted in a manner that is consistent with surrounding provisions',

86 Geoff Roberts, 'Rule 168', in Mark Klamberg (ed.), Commentary on the Law of the International Criminal Court (Case Matrix Network, 18 September 2017), www.casematrixnetwork.org/cmn-knowledge-hub/icc-commentary-clicc/ commentary-rules-of-procedure-and-evidence/commentary-rpe-ch-9/\#c35o1.

87 Schabas and Ambos, supra note 78, p. 970 (emphasis added); see also Lamb, supra note 69, p. 764 .

88 Bemba et al., Urgent Request, para. 39.

89 ICC, Prosecutor v. Bemba et al., Case No. o1/05-01/13, Trial Chamber viI, Decision on Bemba Defence Urgent Request Following DRC Election Decision, 14 September 2018, para. 8 (emphasis added).

90 ICC, Prosecutor v. Bemba et al., Case No. o1/05-01/13, Trial Chamber viI, Transcript of Hearing, 4 September 2019, p. 56, lines 14-16. 
particularly Article 27(2) (irrelevance of official capacity). ${ }^{91}$ The Defence relied on the recent Appeals Chamber judgment in Prosecutor v. Omar Hassan Ahmad Al-Bashir, which found that Article 27(2) has 'vertical effect' on states by imposing an obligation on them to accede to a request by the ICC for the arrest and surrender of an individual and removes any applicable head of state immunity to which that person may be entitled. ${ }^{92}$ Accordingly, the Defence advanced the view that Article 23 must have vertical effect because the provisions of Part 3 of the Statute should be interpreted consistently. ${ }^{93}$ The Defence noted that Article 23 is phrased in similar terms to Article $27(2)$ insofar as neither provision is explicitly confined to the powers of the ICC, implying that Article 23 is an absolute bar to the imposition of subsequent punishments by any court. ${ }^{94}$ The Defence also advanced the view that Article 23 would be rendered meaningless if it did not oblige states to refrain from imposing additional punishments as this would frustrate the object and purpose of Article 23 which regulates the penalties that may be imposed upon a defendant. ${ }^{95}$

However, the Appeals Chamber was unpersuaded by this argument and unanimously rejected the Defence's appeal. The Appeals Chamber affirmed Trial Chamber viI's interpretation of Article 23 and emphasised that it is not for the ICC to intervene in domestic electoral proceedings. ${ }^{96}$ The Appeals Chamber found that the DRC Constitutional Court's ruling 'does not amount to a criminal proceeding' and therefore does not subject Bemba to parallel criminal proceedings and punishments. ${ }^{97}$ Rather, the decision 'is limited to the eligibility assessment of presidential candidates ... without making any determinations as to Mr Bemba's guilt.98

$91 \quad$ Ibid., p. 56, line 25 - p. 57 , line 1.

92 See ICc, Prosecutor v. Omar Hassan Ahmad Al-Bashir, Case No. o2/o5-01/o9 OA2, Appeals Chamber, Judgment in the Jordan Referral re Al-Bashir Appeal, 6 May 2019, paras. 121-126, 132.

ICC, Prosecutor v. Bemba et al., Case No. o1/05-01/13, Appeals Chamber, Article 82(1) (a) Appeal of Mr Jean-Pierre Bemba Gombo against the Decision of Trial Chamber viI entitled 'Decision Re-sentencing Mr Jean-Pierre Bemba Gombo, Mr Aimé Kilolo Musamba and Mr Jean-Jacques Mangenda Kabongo', 17 September 2018, para. 184.

94 Ibid., para. 185 .

95 Ibid.

96 ICc, Prosecutor v. Bemba et al., Case No. o1/05-01/13, Appeals Chamber, Judgment on the Appeal of Mr Jean-Pierre Bemba Gombo against the Decision of Trial Chamber viI of 17 September 2018 entitled 'Decision Re-sentencing Mr Jean-Pierre Bemba Gombo, Mr Aimé Kilolo Musamba and Mr Jean-Jacques Mangenda Kabongo', 27 November 2019, para. 155. Ibid.

$98 \quad$ Ibid. 
The Appeals Chamber therefore closed the door on the possibility that Article 23 prevents states from imposing civil sanctions. However, significantly, it did not rule on whether Article 23 may prevent states from imposing criminal punishments. ${ }^{99}$ Furthermore, the Appeals Chamber did not rule on whether Article 23 has 'vertical effect' and thereby imposes an obligation upon state parties to the Rome Statute.

\subsection{The Future Relevance of Article 23}

The conclusion that Article 23 does not prevent the imposition of a civil penalty, such as a declaration of Bemba's ineligibility to run for president, sits comfortably with the provision's drafting history. At the Rome Conference, the draft Statute prepared by the Preparatory Committee included: (i) a provision which provided for disqualification from office as a penalty for persons convicted of crimes by the Court; and (ii) a provision which provided for 'a suspension or loss of right' as a penalty for persons convicted of crimes by the Court. ${ }^{100}$ The drafting history of Article 77 shows protracted debate among states as to whether it would be appropriate for the Court to have the power to impose penalties such as disqualification, disenfranchisement and the 'suspension or loss of a right'.101 Several delegations were in favour of allowing the Court to order disqualification from political office. ${ }^{102}$ However, at the Preparatory Committee fifth session in December 1997, a number of delegates expressed doubt as to what 'a suspension or loss of right' meant and the reference to 'a suspension or loss of a right' was subsequently dropped from the draft Statute. ${ }^{103}$ 'Disqualification' was included in the draft Statute alongside a footnote stating that ' $[\mathrm{s}]$ ome delegations held the view that such a provision would

99 In international human rights law, ne bis in idem attaches only to criminal offences. It does not apply to sanctions such as disciplinary measures: UnHRC, Gerardus Strik v. The Netherlands, Case No. 1001/2001, Decision on Admissibility, 1 November 2002, para. 7.3. William R. Pace, 'Initial Summary Reports on December 1-12 Meetings of the United Nations Preparatory Committee on the Establishment of an International Criminal Court', 18 December 1997, 5 th PrepComm, www.iccnow.org/documents/5PrepCmtSummaryCICC. pdf, accessed 26 April 2020.

Ibid.

102 Women's Caucus for Gender Justice in the International Criminal Court, 'Recommendations and Commentary for December 1997 PrepCom on the Establishment of an International Criminal Court', www.iccnow.org/documents/WomensCRecomm.pdf. See R.E. Fife, 'Penalties', in R.S. Lee (ed.), The International Criminal Court: The Making of the Rome Statute (Kluwer Law International, London, 1999), 319-344, p. 329. 
give rise to difficult issues of enforcement:.104 The provision (draft Article 75 (c) (i)) was expressed as follows:

(c)(i) [[disqualification from seeking public office for the person's terms of imprisonment and any further period of time that may be imposed] [in the modality and to the extent that the penalty could be imposed in accordance with the laws of the State in which such a penalty is to be enforced];]/147/.

This provision was eventually dropped from the draft Statute due to the concerns expressed that it would be too difficult to enforce and would be best left to the discretion of states. ${ }^{105}$ The position taken by the Appeals Chamber in Prosecutor v. Bemba et al., when understood in light of this drafting history and when viewed from a state sovereignty perspective, is logically sound. The ICC has no power to intervene in national political processes. It is therefore unsurprising that the Appeals Chamber refused to find that a domestic political sanction falls foul of Article 23 of the Rome Statute.

Significantly, however, the judgment leaves open the possibility that Article 23 may prevent states from imposing additional criminal punishments upon defendants who have already been convicted by the Icc. The Appeals Chamber drew a sharp distinction in its judgment between criminal and civil punishments and emphasised that the DRC subjected Bemba to a civil sanction, not a criminal punishment. ${ }^{106}$ If the DRC Constitutional Court had imposed a criminal punishment upon Bemba - such as a term of imprisonment - as a result of his ICC conviction, it is likely that the Appeals Chamber would have been more concerned with the question of whether such an action contravened Article 23. This possibility has important consequences for how Article 23 relates to Article 2O(2). As we analysed in Part 3, Article $20(2)$ provides very limited protection to ICC defendants. The possibility that Article 23 prevents subsequent criminal punishments may therefore expand the protection offered to ICC defendants beyond that provided by Article $20(2)$.

The Appeals Chamber also left open the question of whether Article 23 has 'vertical effect' and, consequently, imposes an obligation on states to refrain from the imposition of punishments under domestic law. This is a significant

104 Pace, supra note 100, p. 20.

105 See Fife, supra note 103, p. 329.

106 Bemba et al., Judgment on the appeal of Mr Jean-Pierre Bemba Gombo against the Decision of Trial Chamber viI of 17 September 2018 entitled 'Decision Re-sentencing $\mathrm{Mr}$ Jean-Pierre Bemba Gombo, Mr Aimé Kilolo Musamba and Mr Jean-Jacques Mangenda Kabongo', para. 155 . 
unresolved issue and enlivens the potential for a defendant to rely on Article 23 in the future to challenge the imposition of a domestic criminal punishment. It would be interesting to see how the ICC may approach such a challenge. However, it must be recalled that even if the ICC were to find that Article 23 prevents subsequent criminal punishments, a defendant would be limited to seeking declaratory relief. The ICC would, at most, have the power to declare that a state halt any punishment, but would not be able to enforce compliance in any more meaningful way. Instead, it would be left up to the state to decide how to respond to any such ICC declaration.

It is important to note that, similarly to Article 108 discussed in Part 3 above, Article 23 is expressly limited to convicted defendants and therefore provides no protection for a defendant who has been acquitted by the Court, such as Laurent Gbagbo, who intends to run for President of Côte d'Ivoire in the upcoming 2020 elections and it remains to be seen whether there may be any legal attempts to prevent him from doing so. ${ }^{107}$

In light of this limitation and the unresolved questions over the scope of Article 23, we argue that it is best to address the prohibition on subsequent punishments through the national implementing legislation adopted by state parties and the constituent instruments of regional courts whose jurisdictions overlap with that of the ICC.

The Critical Role of Domestic and Regional Best Practice in Implementing the Rome Statute

As we have established, Articles $20(2)$ and 23 of the Statute provide narrow protection from subsequent prosecution and punishment by states and regional authorities. Moreover, we have explored how even if a state party were to impose a punishment upon a defendant that contravened its obligations under Articles $2 \mathrm{O}(2)$ or 23 , the ICC's power to enforce compliance is limited. ${ }^{108}$ Consequently, it is critical to consider how the system of international criminal justice can ensure that a defendant's right not to be tried and punished twice for the same crime is respected by national and regional authorities. In this Part, we argue that this issue is best addressed through the inclusion of

\footnotetext{
107 Peter Penar, 'What the Return of Gbagbo Could Mean for the Ivory Coast's 2020 Election', The Conversation, 17 January 2019, www.theconversation.com/what-thereturn-of-gbagbo-could-mean-for-ivory-coasts-2020-election-10996o. 
adequate safeguards in domestic legislation and the constituent instruments of regional criminal courts.

\section{1 'Positive Complementarity' and Domestic Implementation of the Rome Statute}

Bassiouni once described the combination of prosecution under universal jurisdiction provisions and in the national courts of the territorial state as the 'indirect enforcement system' of international criminal law. This system was distinct from international prosecutions, which formed part of the 'direct enforcement system' of international criminal law.'109 While that might certainly have been true of the ad hoc era, the complementary nature of the ICC's jurisdiction now sees domestic courts as the direct enforcement system of international criminal law.

The Rome Statute is built on the principle of complementarity and the assumption that states can and should take primary responsibility for prosecuting international crimes. Importantly, since the Kampala Review Conference in 2010, a more 'positive' notion of complementarity has emerged. This new dialogue focuses less on complementarity being a question of when the ICC does or does not have jurisdiction, and turns to consider how the ICC, in particular, the Prosecutor, can better engage with domestic systems, authorities and courts to strengthen the implementation and enforcement of the Rome Statute at the national level.

While the Rome Statute does mandate that states implement legislation to allow them to cooperate with the ICC, ${ }^{110}$ it does not impose any obligation on a state to enact legislation providing for the domestic prosecution of Rome Statute crimes. Nevertheless, since the Rome Statute was adopted in 1998, around half of the state parties have implemented some form of domestic legislation covering international crimes. Moreover, many states have invested their courts with universal jurisdiction, which facilitates the domestic prosecution of international crimes even where no traditional basis of jurisdiction exists. Of course, the precise way in which states implement treaties into their domestic laws varies significantly across legal systems. However, it is nevertheless highly likely that as states continue to enact implementing legislation and

\footnotetext{
109 Charles Chernor Jalloh, 'The Place of the African Criminal Court in the Prosecution of Serious Crimes in Africa', in Charles Chernor Jalloh and Ilias Bantekas (eds.), The International Criminal Court and Africa (Oxford University Press, Oxford, 2017), 289-319, p. 289 . 
strengthen their capacity to prosecute international crimes at home, we will no doubt see an increase in ne bis in idem questions at the 'front end' of ICC proceedings (i.e. in respect of Article 17(1) and Article 20(3)). As this article has argued, it is also likely that we will see complicated questions at the back end' of an ICC proceeding (i.e., in respect of Article 2O(2)), where the ICC was 'seized' first in time. Such an outcome was foreseen by Judges Van den Wyngaert and Ongena in 2002, who recognised that complementarity made conflicts of jurisdiction more likely than at the ad hoc tribunals and that, consequently, Article 20(2) assumed even greater importance. ${ }^{111}$

Of course, ICC Chambers are constrained by the statutory framework within which they operate and, in Parts 3 and 4 above, we have pointed to the difficulties presented by the fact that the ICC does not have the power to interfere in the domaine réservé of domestic proceedings. Consequently, where an ICC Chamber observes a deficiency in the Statute, it has very few tools at its disposal, short of urging state parties to consider amendments. ${ }^{112}$ Therefore, we argue that the most relevant and valuable tool to increase protections from subsequent prosecution and punishment is carefully drafted and robust domestic implementing legislation. Given that ne bis in idem applies within one jurisdiction only, it falls to domestic legislation to safeguard defendants from domestic prosecutorial overreach. ${ }^{113}$

A review of current national implementing legislation reveals that the legislation of some states is entirely silent on the issue, or only considers the interaction between two national courts prosecuting international crimes, overlooking the relationship between a national proceeding and an ICC proceeding. ${ }^{114}$ The Commonwealth's Model Law to Implement the Rome Statute (Model Law) reveals a concerning complacency when it comes to the issues of both ne bis in idem and nulla poena sine lege. The Model Law notes that because Articles 20 to 24 of the Rome Statute 'reflected principles of such a

111 Christine Van Den Wyngaert and Tom Onega, 'Ne Bis In Idem Principle, Including the Issue of Amnesty', in Antonio Cassese (ed.), The Rome Statute of the International Criminal Court: A Commentary (Oxford University Press, Oxford, 2002), 705-733, p. 710.

112 Bemba, Decision on Mr Bemba's Claim for Compensation and Damages, para. 69 .

113 Amnesty International, 'The International Criminal Court: Checklist for Effective Implementation', July 2000, www.amnesty.org/download/Documents/1400oo/ ior40o1120ooen.pdf.

114 Amnesty International, 'Democratic Republic of Congo: Comments and Recommendations of the July 2003 Draft Law Implementing the Rome Statute of the International Criminal Court', 9 August 2004, www.amnesty.org/en/documents/AFR62/oo8/2004/en/. 
fundamental nature that they would be recognised already in common law legal systems ... it recommended that these not be mentioned in the model law' 115 Whilst it is true that these are fundamental common law principles, that does not provide guidance on the exact process to be followed in respect of subsequent proceedings and the complex issues associated with the characterisation of domestic crimes and their correlation to the international core crimes. The Model Law goes on to propose optional sections clarifying the extent to which a state can 'go behind' an earlier prosecution of another state but, as with the majority of implementing legislation, is then otherwise silent on the interaction between the ICC and domestic courts.

By way of other example, the Italian Penal Code (Rinnovamento del Giudizio) provides that where a crime is committed on Italian territory, a person tried 'abroad' can be tried again by domestic courts. As Amnesty International has raised with some concern, Italy's implementing legislation should include a provision at the least clarifying that the provision, and the phrase 'abroad', does not apply to trials at the ICC, and at best, forbidding a new Italian trial for a crime for which the person has already been convicted or acquitted by the ICC. ${ }^{116}$

In contrast, Australia's implementing legislation provides that:

A person cannot be tried by a federal court or a court of a State or Territory for an offence under this Division if the person has already been convicted or acquitted by the International Criminal Court for an offence constituted by substantially the same conduct as constituted the offence under this Division. ${ }^{117}$

Despite uncertainty as to what would constitute 'substantially the same conduct', the protection afforded by this provision is much broader than that provided by the Rome Statute in Article 2o(2). Whilst it remains to be seen how Australian courts may interpret the phrase 'substantially the same conduct', it is patent that the use of the modifier 'substantially' invites the court to consider nuanced questions of what constitutes 'substantial' and 'conduct'. This exercise in interpretation is, in our view, valuable in that is does not reduce

115 Commonwealth Secretariat, 'Model Law - Rome Statute of the International Criminal Court', The Commonwealth Secretariat, 2017, p. 72, www.asp.icc-cpi.int/iccdocs/asp_docs/ library/asp/MODEL_LAW-Commonwealth-ICC-ENG.pdf.

116 Amnesty International, 'Italy and the International Criminal Court', September 2005 www. amnesty.org/download/Documents/840oo/eurzooog2oo5en.pdf. 
questions of ne bis in idem to a matter of form over substance in the same way that Article 20(2) does. As we noted in Part 3, state practice reveals that even where states have implemented the Rome Statute Article 5 crimes, they continue to resort to charging individuals with ordinary crimes (such as murder). ${ }^{118}$ Therefore, we propose that best practice implementation of the Rome Statute would include a provision similar to that which appears in the Australian legislation on the basis that it provides for a more substantive consideration of the facts and conduct underlying the crime, rather than the mere characterisation or labelling of the crime.

As we have shown through our analyses of Prosecutor v. Katanga and Prosecutor v. Bemba et al., the ICC lacks the power to interfere with domestic prosecutions. Therefore, the 'protection' of individuals that face subsequent domestic proceedings rests solely on the observance of 'transnational ne bis in idem', which, as we outlined in Part 3 above, remains limited. ${ }^{119}$ Clearly, the operation of robust domestic laws that confront questions of ne bis in idem is vital to bolster the narrow protections provided at the international level. If states are to take a more active and 'direct' role in ending impunity for international crimes, the lines delimitating who can prosecute, when, and for what need to be drawn with greater clarity.

\subsection{The Proliferation of Regional and Hybrid Criminal Courts}

Along with increased domestic implementation and prosecution, we are also witnessing an increased use of hybrid courts, bilateral regimes and the advent of regional courts. ${ }^{120}$ The reference in Articles $20(2)$ and $20(3)$ to 'other courts' was, at least at the time of drafting, a reference to national courts. ${ }^{121}$ However, the proliferation of other adjudicatory bodies with overlapping jurisdiction mandates a consideration of the protections afforded to individuals subject to the jurisdiction of both the ICC and a regional or hybrid court.

In 2014, the African Union (AU) adopted the Protocol on Amendments to the Protocol on the African Court of Justice and Human Rights (Malabo

\footnotetext{
118 See Kastner, supra note 42, p. 35; see also Ward N Ferdinandusse, Direct Application of International Criminal Law in National Courts (TMC Asser Press, The Hague, 2006), 89-127.

119 Tallgren and Coracini, supra note 20, pp. 686-687.

120 Ernst Hirsch Ballin, 'The Value of International Criminal Law: How Much International Criminal Justice Can the World Afford?', 19 International Criminal Law Review (2019) 201213, p. 201.

121

Wyngaert and Onega, supra note 111, p. 723.
} 
Protocol) which, ${ }^{122}$ when it enters into force, will extend the jurisdiction of the African Court of Justice and Human Rights (ACJHR) to cover the prosecution of international crimes, including genocide, war crimes and crimes against humanity. ${ }^{123}$ Accordingly, the subject-matter and geographical jurisdiction of the ACJHR will overlap with that of the ICC. Moreover, thirty-four out of the fifty-five member states of the AU are also state parties to the Rome Statute. Although there has been limited uptake by AU member states in ratifying the Malabo Protocol - with only fifteen out of fifty-five AU member states having done so - it is nevertheless imperative to develop a precise understanding of how ne bis in idem applies between these two courts given the extent of jurisdictional overlap between the ACJHR and the ICC, as well as the fact that the motivation for the establishment of the ACJHR was numerous African states' express dissatisfaction with the ICC. ${ }^{124}$

Article $46 \mathrm{I}(2)$ of the Malabo Protocol outlines the ne bis in idem provision:

Except in exceptional circumstances, no person who has been tried by another court for conduct proscribed under Article 28A of this Statute shall be tried by the Court with respect to the same conduct unless the proceedings in the other Court:

(a) Were for the purpose of shielding the person concerned from criminal responsibility for crimes within the jurisdiction of the Court;

(b) Otherwise were not conducted independently or impartially in accordance with the norms of due process recognized by international law and were conducted in a manner which, in the circumstances, was inconsistent with an intent to bring the person concerned to justice.

Article $46 \mathrm{I}(2)$ appears to protect an individual from an ACJH R proceeding subsequent to a trial (regardless of the outcome) by 'another court'. The reference to 'another court' will likely be interpreted to include other domestic courts as well as hybrid and international courts, including the ICc. The provision protects defendants from trial at the ACJHR 'with respect to the same conduct' for which they were tried by another court, in a similar manner to the drafting

Protocol on Amendments to the Protocol on the African Court of Justice and Human Rights (adopted 27 June 2014, not yet in force).

123 Ibid., Art. 28A(1); see Amnesty International, 'Africa: Malabo Protocol: Legal and Institutional Implications of the Merged and Expanded African Court', 22 January 2016, www.amnesty.org/en/documents/afro1/3063/2016/en/.

124 See, e.g. Eki Yemisi Omorogbe, "The Crisis of International Criminal Law in Africa: A Regional Regime in Response?' 66(2) Netherlands International Law Review (2019) 287-311. 
of Australia's implementing legislation. While it remains to be seen what will constitute 'exceptional circumstances' for the purposes of Article 46I(2), in our view the Malabo Protocol will provide robust protection for defendants against subsequent proceedings at the ACJHR.

In contrast, the law establishing the Special Criminal Court (SCC) in the Central African Republic (CAR) does not specifically address ne bis in idem despite the jurisdiction of the SCC overlapping with that of the ICC. ${ }^{125}$ The SCC could therefore authorise the prosecution of a defendant who has already been convicted or acquitted by the ICC. This concern is not far-fetched, given that the ICC Office of the Prosecutor currently has two ongoing investigations into alleged international crimes committed in the CAR and is currently prosecuting Alfred Yekatom and Patrice-Edouard Ngaïssona for war crimes and crimes against humanity allegedly committed in the CAR between 2013 and $2014 .{ }^{126}$ Yekatom and Ngaïssona may therefore face a subsequent prosecution at the sCC based on the same conduct underlying the ICC charges, despite a conviction or acquittal by the ICC.

Most recently, in January 2020, the Government of Sudan agreed with armed groups to establish a Special Court for Darfur with jurisdiction to try war crimes and crimes against humanity committed during the ongoing conflict in Darfur. ${ }^{127}$ While the Special Court's jurisdiction has not yet been codified, it is probable that it will overlap to some extent with the jurisdiction of the ICC to try war crimes and crimes against humanity, raising the possibility that defendants could be subject to subsequent prosecution and punishment in the aftermath of an ICC trial.

The increased investigation, prosecution and adjudication of international criminal conduct, whether by regional or international bodies is, most would say, a positive trend. That much is uncontroversial. However, for that increased interest and activity to be sustainable, greater consideration must be given to the consequences of overlapping jurisdiction and admissibility.

\footnotetext{
125 Central African Republic, Loi Organique No 15/oo3 Portant Création, Organisation et Fonciennement de la Cour Pénale Speciale, Art. 3.

126 ICC, Prosecutor v. Alfred Yekatom and Patrice-Edouard Ngaïssona, Case No. ICC-o1/14-o1/18, Trial Chamber II, Decision on the Confirmation of Charges against Alfred Yekatom and Patrice-Edouard Ngaïssona, 2o December 2019.

127 Sudan Tribune, 'Sudan, Armed Groups Agree to Establish Special Court for Darfur Crimes', 21 January 2020, www.sudantribune.com/spip.php?article68873=.
} 
Two decades on from the adoption of the Rome Statute, international criminal law academics and practitioners alike have developed a robust understanding of, and can confidently respond to, common issues arising at the outset of an ICC proceeding, such as whether the ICC has jurisdiction to prosecute and whether a case is admissible before the Court. To date, the organs of the Court have, understandably, prioritised getting cases through the doors of the Court and to the point of verdict as efficiently as possible. However, as the Court now looks to its next twenty years, and the number of completed cases and released defendants grows, the international criminal law community must shift its attention to the aftermath of the proceedings.

Most importantly, as we have argued, the legality of subsequent prosecutions and punishments to which defendants may be subject following their conviction or acquittal requires urgent attention. Irrespective of complex arguments over the normative or moral justifications for subsequent prosecutions and punishments in the aftermath of ICC trials, this article has demonstrated that the principles of ne bis in idem and nulla poena sine lege in the Rome Statute do not adequately protect defendants from the imposition of subsequent prosecutions or punishments by domestic and regional authorities because of the narrow ways in which they have been drafted and the restrictive ways in which they have been interpreted.

On first thought, it may seem desirable to address this issue via amendments to these provisions in the Rome Statute. We have, however, instead argued that greater attention should be paid to the inclusion of protections from subsequent prosecutions and punishments in the legislation adopted by states to implement the Rome Statute into their domestic laws. The rationale for this is twofold. First, even if consensus could be achieved among state parties to amend the drafting of Articles 20(2) and 23 in the Statute, the ICC lacks the power to enforce compliance with these provisions as they are essentially matters of domestic law. Secondly, under the principle of complementarity, states enjoy the primary role in the enforcement of international criminal law and, accordingly, should ensure that any lacuna in the Rome Statute is filled by robust protections in domestic legislation.

A sustainable system of international criminal justice was never intended to rest solely with the ICC. Increased support for domestic and regional responses to international crimes should be welcomed. However, it must be complemented by a deeper understanding of how, in line with the fundamental principles of ne bis in idem and nulla poena sine lege, we can ensure protections for defendants after the Court has delivered its judgment. 